\title{
Google Maps as Media to Promote Heritage Management: A Comparative Studi Between Wayang Museum and Kakayon Museum
}

\author{
Nurhablisyah $^{1}$, D Pratama ${ }^{2}$, A Nurfarkhana \\ Universitas Indraprasta PGRI, Jakarta Selatan, Indonesia ${ }^{1,2,3}$ \\ \{nurhablisyah@unindra.ac.id $\left.{ }^{1}\right\}$
}

\begin{abstract}
Media sharing as part of new media allows various promotion gather in one hand. Google maps are feature provide by Google that gives insight to people to find their way through the internet map. But, not only that, but internet users also could make their review while visiting a certain place. This kind of access could be used for management to promote their site or give direct feedback to the audience. Wayang Museum and Kakayon Museum are the same museums provide information about Wayang as Indonesia's heritage. There is a huge gap between these two museum from google map's reviews and recommendation. Wayang Museum located in Jakarta, collected 2.226 reviews and mostly gave 4.4 stars and recommended visitors to come to the museum. But Kakayon Museum located in Bantul Yogyakarta only gain 197 reviews and 4.1 stars. For the overall review, Wayang Museum has a good review, especially about the management. In the other hand, Kakayon Museum was praised about their puppet's collection and polite staff. This study describes how internet users now days is more active to promote and recommend their thought after visiting a new place. This kind of activity was supported by using an internet application called Google Map. Tourism management could also use the application to promote their site in effective way and respond to the visitor's reviews to have better management.
\end{abstract}

Keywords: Heritage Promotion, Google Map, Wayang Museum and Kakayon

\section{Introduction}

Friedman (2007) in Nasrullah (2015) [1] explained how technology could transform the world in man's hand and brought "the world is flat." New media related to communication technology and internet connection allows everyone to access any information from any place and time. New media or cyber media allows any information to be shared by everyone. Traditional media newspaper, television, radio, book) needs to adapt to the new era of media. Naratama, Chief Editor of VOA Indonesia based in New York, said in National Conference of Industry 4.0 and Television, $29^{\text {th }}$ November 2018 , if television won't change their perspective in program producing, it would vanish, and lost its viewers. Media change also influenced how people selling their product, including cultural assets. One successful phenomenon these days is how South Korea boost its tourism by maintaining the media industry. Korea is known as one of the fastest internet speed in the world and has a major technology development. 
South Korea, through Korea's National Internet Development (NIDA), found that 90,8\% internet users actively access entertainment content such as film, drama, music, television program, etc. Since 2007, social media have been giving internet users to spreading Korean culture to the world [2]. The result of successful promotion by using new media, Film and Television industry in South Korea supported national GDP 17,454 Billion won [3]. South Korea Wave (Hallyu Wave) successfully increasing international tourist from Japan, Taiwan, China, South East Asia, and other countries [2].

Media sharing is a type of social media which facilitate the users with various media such as pictures, podcasts, video, documents or files, audio, etc. Media sharing could be found in youtube, Flickr, photo-bucket, and others [1]. Google map also provide that facilities, anyone who's having Google account could share their picture or videos. Google map is a media not only use for tracing destination but also recommending to travelers. For tourist management, Google's facilities could help them increase their services and connect to the customer directly.

Wayang Museum and Kakayon Museum, both are cultural assets which collect wayang (Indonesia's traditional puppets). Wayang Museum located in Kota Tua, Jakarta. It has 4.4 stars recommendation from 2.226 reviews since 2017. Kakayon Museum, located in BantulYogyakarta, it has 4.1 stars recommendations from 197 reviews since 2017. Both of the museums, begin recommended online in the same year, but Wayang Museum collects more stars and visitors rather than Kakayon Museum. The reviewer also gave advise to the museum's management that could be read by other users. This study will show, how Heritage management could be review and promote through Google map recommendations, by comparing reviews from the users.
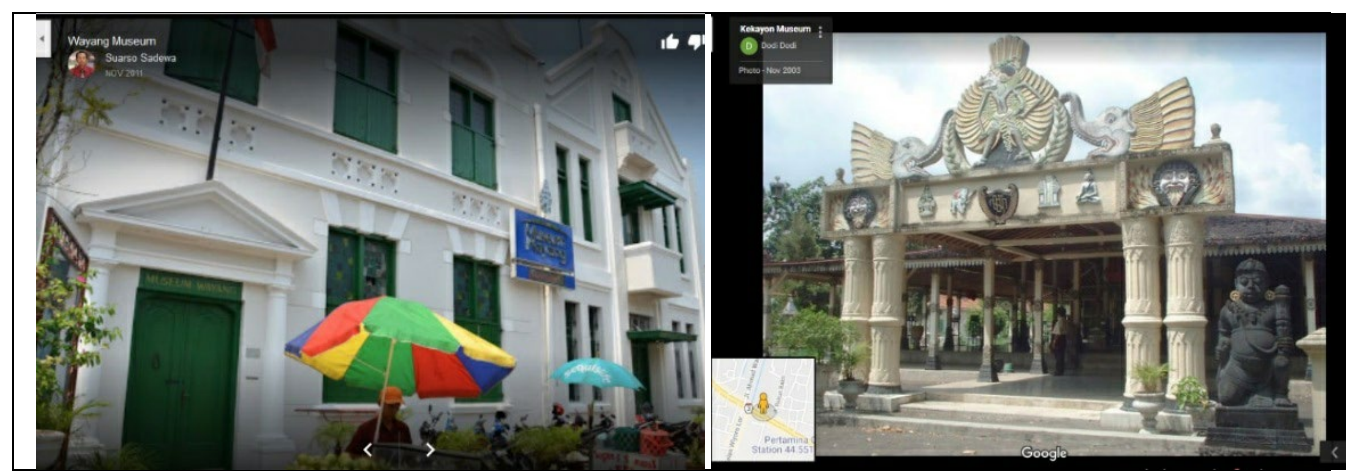

Figure.1. Wayang Museum (left) and Kakayon Museum (Right)

Source: Google Map (downloaded, January $6^{\text {th }}, 2019$ )

Figure.1. Shows pictures of being uploaded by users when visiting the museum. Another user not only read the reviews but also enjoy the picture. Google also give redemption for users who always reviewed and shared pictured. Redemption could be changed with coupons such as food, goodie bags, etc. 


\section{Literature review}

\subsection{Heritage Management}

Heritage management could be defined through multidisciplinary. Researchers from anthropology, sociology, tourist studies, museum studies, prefers to analyze this scope in recent years. The word of "heritage" has a broad meaning, not just as archaeology site, monument, paintings, memorial, sculptures, and other artifacts, but also includes philosophy, sports, language, literature, ideology, poetry, and arts. Heritage linked to the past and present. One of the most influential factors is audience. Without audience, heritage gains a little value. Hence, the indicator of a successful museum is how many audiences attend and willing to visit [4]. To increase the visitors to the heritage site, management needs to provide better infrastructure and information. Another term related to this matter is tourism heritage. European Commission, 2007, explained various kinds of heritage tourism, such as; archaeology, art, architecture, tours of churches and cathedrals, historic tours, museum, music festivals, opera, military history, and pilgrimages. All these diversity treasure remains as assets for the knowledge economy and in terms of inter-cultural skill useful in world economy [5]. Cultural heritage management (CHM), have a complex relation to the social, political, and economic context. A nation's desire to preserve its heritage is almost always contrary with economic development, particularly natural resource exploitation, infrastructure improvements, and urban renewal, which result in threats to heritage resources [6].

\subsection{Google Map}

Google map is sharing media but also application that could be downloaded in a smartphone. This type of service from Google API as media which use location-based service method. Data location in an application could be used by the owner of the tourist site and the user. The user could also transfer the information to the other user. There are 3 main functions of the media; (1) to informs the nearest route (location), (2) to visualize the tourism spot to the users (3) to recommend to the user. While users who not download the application, still can access the media through Geotagging from the website [7]. Wayang Museum and Kakayon Museum, are a treasure of the cultural assets of Indonesian's puppets. Wayang Museum runs by Jakarta Government, but Kakayon Museum own privately by an individual (the owner was a professor whose researched and collect puppet for his study. Now, the museum was runs by his son. In this study, heritage management is being seen as infrastructural and hospitality that captured by the visitors. This study is comparing two museum by clustering the reviews from a visitor. The cluster divided into four parts; (1) infrastructure, (2) staff hospitality, (3) another facility, (4) museum program.

\section{Result and discussion}

Wayang Museum and Kakayon Museum started to be reviewed in 2017. But, the amount of reviewer's gap is very wide, 11:1 for the Wayang Museum. Visitors . Wayang Museum Jakarta gained 4.4 stars, means most of the visitor recommended audience to come. Kakayon Museum gained 4.1 stars, but the total reviewers too left behind from Wayang Museum. Mostly visitors complained about air conditioners in Wayang Museum which not support the massive crowded on Monday (the highest day of the visitors). Kakayon Museum gained more 
complained due to building maintained, especially the parking lot in front of the museum which used by wreckage old cars.

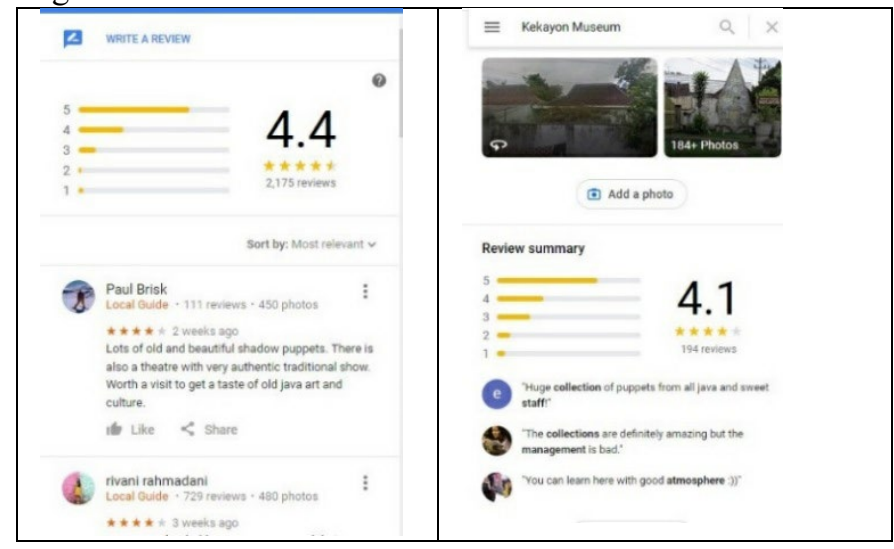

Figure 2. Wayang Museum's Review (left) and Kakayon Museum's Review (Right)

$$
\text { Source: Google Map (downloaded, January } 6^{\text {th }} 2019 \text { ) }
$$

Figure 2. shows rates and reviews from the visitors. The user needs to log in with google account, so the identity and the comments of the user could be seen by everyone. For museum administrator or management, these reviews could be replied. The reply could also read by another user too. Therefore, how management responds the comments would imply how the museum taking care of the audiences.

Wayang Museum located in Kota Tua Jakarta. In this site, there are several museums located in the same complex. Kota Tua is a tourism site that attracted many tourists from local and international. Some of the museums are beside Wayang Museum are; Jakarta History Museum or Fatahilah Museum, Museum of Fine Arts and Ceramics, Mandiri's Bank Museum, Indonesia's Bank Museum. As tourism site run by the city government, Wayang Museum has more financial support and facilities to attract visitors. Museum Kakayon, located in Bantul Yogyakarta. The owner of the museum is a professor who collects a lot of puppets. The puppets also become his subject of study. But after the professor died, the museum was run by his son. Kakayon Museum has a rare puppets collection and other treasure information about Wayang in Indonesia, but the condition of the museum was being complained by the viewers. The table below will show, the summary of reviews comparison between Wayang Museum and Kakayon Museum.

Table 1. Reviews Comparison Between Wayang Museum and Kakayon Museum

\begin{tabular}{lll}
\hline Elements & Wayang Museum & Kakayon Museum \\
\hline Total Reviews & 2226 & 197 \\
\hline Total 1 star $(*)$ & 50 & 7 \\
\hline Total 2 stars $(* \star *)$ & 27 & 13 \\
\hline Total 3 Stars and More & 2.098 & 177 \\
\hline First review & 2017 & 2017 \\
\hline
\end{tabular}




\begin{tabular}{|c|c|c|}
\hline Ticket price & IDR 5.000 & IDR 10.000 \\
\hline Infrastructure & $\begin{array}{l}\text { Mostly complained about } \\
\text { museum has little lighting } \\
\text { and lack of air conditioner. }\end{array}$ & $\begin{array}{l}\text { Mostly complained } \\
\text { about museum has little } \\
\text { lighting and lack of air } \\
\text { conditioner. The } \\
\text { condition of the parking } \\
\text { lot is not good, many } \\
\text { wreckage old cars parks } \\
\text { there. The grass in the } \\
\text { yard was not } \\
\text { maintained. Heavy dust } \\
\text { in puppets collection. } \\
\text { And when the ballroom } \\
\text { was rent to the wedding, } \\
\text { the museum was closed } \\
\text { to the public }\end{array}$ \\
\hline Peak day & Sunday and Monday & Sunday and Monday \\
\hline Staff hospitality & $\begin{array}{l}\text { Nice and friendly staff, but } \\
\text { some reviewers found } \\
\text { illegal staff offering tour } \\
\text { guide for visitors }\end{array}$ & Nice and friendly staff \\
\hline Another program & $\begin{array}{l}\text { In Monday evening, a } \\
\text { visitor may watch wayang } \\
\text { show live }\end{array}$ & $\begin{array}{l}\text { Nothing mentioned by } \\
\text { viewers }\end{array}$ \\
\hline Another facility & $\begin{array}{l}\text { Provide prayer room and } \\
\text { proper toilet }\end{array}$ & $\begin{array}{l}\text { A prayer room is not } \\
\text { available }\end{array}$ \\
\hline Best part & $\begin{array}{l}\text { Puppet collections and } \\
\text { atmosphere }\end{array}$ & $\begin{array}{l}\text { Puppet collections and } \\
\text { atmosphere }\end{array}$ \\
\hline Management feedback & $\begin{array}{l}\text { Some reviewers got direct } \\
\text { feedback from the } \\
\text { management }\end{array}$ & No feedback \\
\hline
\end{tabular}

The table shows Wayang Museum managed more compare to Kakayon Museum. Even though the ticket price of Kakayon Museum is higher than Wayang Museum, but it look like won't covered the financial expenditure of the museum. Kakayon Museum need to produce more income, therefor they rent the venue to a wedding party. But this policy caused visitor not able to enter the museum. May ancient cars park in the parking lot without description. Some viewers wonder, it would be more interesting if the cars were maintained and gave more information.

Figure 3. Shows the landscape of the Wayang Museum (left) and Kakayon Museum (right). Both of the pictures was taken and shared by the users. The photos visualized the different between the museum's management in maintaining the outside look of the museum. Wayang Museum indicates a clean, well manage and neat image. But Kakayon Museum implies a dirty, not well maintained and financial problem. 


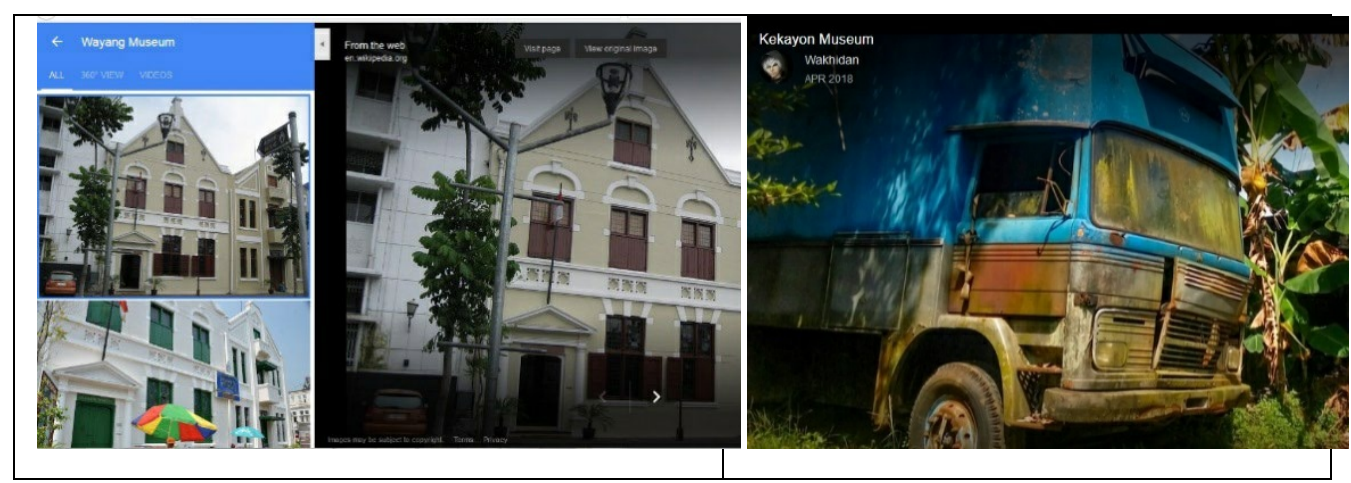

Figure.3. Outside views of Wayang Museum (left) and Kakayon Museum (Right)

Source: Google Map (downloaded, January $6^{\text {th }} 2019$ )

Google map recommendation is increasing every day, but Kakayon Museum shows a very slowly increasing compare to Wayang Museum. By analyzing the visitors reviews, museum management could use it as a control system to provide a better service to the audience, so the heritage could be used well. Museum is a part of national heritage. Therefore local government and society have a responsibility to taking care and preserved it.

\section{Conclusion}

Information technology grows very rapidly, this phenomenon makes every commercial field must adapt to the new technology era. Television and media traditional are no longer powerful to promote. New media, especially social media become sharing media among internet users. They not only share pictures, videos but also recommendations and thought about something. To preserve the heritage site, museum administrator needs to provide this activities. Museum Wayang located in Jakarta reached 2.226 reviews from visitors and museum administrator response to the viewers. Museum Kakayon located in Yogyakarta reached 197 reviews and museum administrator didn't access Google map account to respond the viewers comments. First reviews form the museum was wrote in 2017. Museum Wayang has more visitors and have 4.4 stars. Most of them recommends Museum Wayang as good destinations compare Kakayon Museum.

\section{References}

[1] R. Nasrullah, Media Sosial Perspektif Komunikasi, Budaya, dan Sosioteknologi, 1st ed. Bandung: Simbiosa Rekatama, 2015.

[2] A. Sari, I. Chartika, and J. and N. S. Route, "Hallyu Sebagai Fenomena Transnasional," J. Online Mhs. Bid. Ilmu Sos. dan Ilmu Polit., vol. 1, no. 1, pp. 1-14, 2014.

[3] Oxford Economics, "The economic contribution of the film and television industries in South Korea," Oxford Economics. [Online]. Available: https://www.oxfordeconomics.com/publication/open/222582.

[4] L. Shepherd, R. J., and Yu, "Heritage Management, Tourism, and Governance in China Managing the Past to Serve the Presents." Springer, 2013.

[5] M.-R. Surugiu and C. Surugiu, "Heritage Tourism Entrepreneurship and Social Media: 
Opportunities and Challenges," Procedia - Soc. Behav. Sci., vol. 188, pp. 74-81, May 2015.

[6] T. Majewski and J. H. Altschul, "Heritage Management," in The Encyclopedia of Archaeological Sciences, Hoboken, NJ, USA: John Wiley \& Sons, Inc., 2018, pp. 1-5.

[7] M. H. Mz, "Aplikasi Rekomendasi Spot Area Wisata Berbasis Android dengan Teknik Geotag," An Int. J. Inf. Commun. Technol., vol. 2, no. 1, pp. 2-6, 2017. 